members of a family with a high incidence of acute myeloid leukaemia (Snyder et al., 1970). Perhaps there is a similar increased susceptibility to malignant transformation by viruses in this family also. Other factors might have had a contributory effect-for example, the propositus appeared to be deficient in monocytes and macrophages, which are important in the defence against viral pathogens (Silverstein, 1970).

The possible role of immunodeficiency in the pathogenesis of leukaemia has already been mentioned (Galton and Spiers, 1971), and in this context it is interesting that low concentrations of IgA were present in several members of the family (Fig. 1) as in another, rather similar familial acute myeloid leukaemia (Snyder et al., 1970). In the present family it appears that the IgA deficiency was inherited from the mother (I 2) and was not a simple dominant characteristic. That this association between inherited leukaemogenic factors and immunodeficiencies might not be fortuitous is suggested by the work of Sutton et al. (1969), who found lower concentrations of IgA in siblings of leukaemic children. Further evidence is provided by the numerous reported cases of the association of lymphoreticular malignancy and cellular and humoral immunodeficiency (Freeman et al., 1970; Galton and Spiers, 1971; Potolsky et al., 1971).

Although genetic predisposition seems the most likely explanation of our findings, the possibility of "vertical" transmission, as in the virus-induced murine leukaemias (Huebner and Todaro, 1969) and as suggested for familial leukaemia in man by Heath and Moloney (1965), must also be considered.

We thank Professor J. V. Dacie, Dr. D. A. G. Galton, and Dr. J. M. Goldman for advice and encouragement; Dr. M. B. Slavin for the immunoglobulin estimations; and Dr. C. O. Carter for his suggestions after reviewing the manuscript. J. K. is a Berry Trust scholar from the Postgraduate Institute of Medical Education and Research, Chandigarh, 12, India.

Requests for reprints should be addressed to D. C., M. R. C. Leukaemia Unit, Royal Postgraduate Medical School, London W.12.

\section{References}

Allen, D. W., and Cole, P. (1972). New England fournal of Medicine, 286, 70. Blair, T. R., Bayrd, E. D., and Pease, G. L. (1966). Journal of the American Medical Association, 198, 21.

Bottomley, R. H., Trainer, A. L., and Condit, P. T. (1971). Cancer (Philadelphia), 28, 519 .

Butel, J. S. (1972). Fournal of the National Cancer Institute, 48, 285.

Carter, C. O. (1969). An A.B.C. of Medical Genetics. London, Lancet.

Catovsky, D., Shaw, M. T., Hoff brand, A. V., and Dacie, J. V. (1971). British fournal of Haematology, 20, 385 .

Dosik, H. et al. (1970). Blood, 36, 341 .
Fitzgerald, P. H., Crossen, P. E., Adams, A. C., Sharman, C. V., and Gunz, F. W. (1966). Fournal of Medical Genetics, 3, 96

Fraumeni, J. F., jun., Vogel, C. L., and DeVita, V. T. (1969). Annals of Internal Medicine, 71, 279.

Freeman, A. I., Sinks, L. F., and Cohen, M. M. (1970). fournal of Pediatrics, 77, 996.

Galton, D. A. G., and Spiers, A. S. D. (1971). Progress in Hematology, 7, 343

Gibson, R. W., et al. (1968). New England fournal of Medicine, 279, 906. Goudsmit, R., Leeuwen, A. M. van, and James, J. (1971). British fournal of Haematology, 20, 557 . Gunz, $\mathrm{F}$. W. (1970). Proceedings of the XIII Congress of the International
Society of Hematology, Munich, p. 48.

Gunz, F. W., and Veale, A. M. O. (1969). Fournal of the National Cancer Institute, 42, 517.

Hayhoe, F. G. J. (1960). Leukaemia: Research and Clinical Practice. London, Churchill.

Hayhoe, F. G. J., Quaglino, D., and Doll, R. (1964). Cytology and Cytochemistry of Acute Leukaemias. London, H.M.S.O.

eath, C. W., jun., and Moloney, W. C. (1965). New England fournal of Medicine, 272, 882.

Huebner, R. J., and Todaro, G. J. (1969). Proceedings of the National Academy of Sciences, 64, 1087.

Humbert, J. R., Hathaway, W. E., Robinson, A., Peakman, D. C., and Githens, J. H. (1971). British fournal of Haematology, 21, 705.

Jensen, M. K. (1968). Acta Medica Scandinavica, 183, 535.

Jensen, M. K. (1971). Acta Medica Scandinavica, 190, 429.

Leeksma, C. H. W., Friden-Kill, L., Brommer, E. J. P., Neuberg, C. W., and Kerkhofs, H. (1965). Lancet, $2,1299$.

Lehrer, R. I., and Cline, M. J. (1969). Ұournal of Bacteriology, 98, 996.

McPhedran, P., Heath, C. W., and Lee, J. (1969). Cancer (Philadelphia), 24, 403 .

Moorhead, P. S., Nowell, P. C., Mellman, W. J., Battips, D. M., and Hungerford, D. A. (1960). Experimental Cell Research, 20, 613.

Nowell, P. C. (1971). Cancer (Philadelphia), 28, 513.
Park, B. H., Fikrig, S. M., and Smithwick, E. M. (1968). Lancet, 2, 532.

Park, B. H., Fikrig, S. M., and Smithwick, E. M. (1968). Lancet, 2, 532.
Potolsky, A. I., Heath, C. W., jun., Buckley, C. E., and Rowlands, D. T., jun. (1971). American fournal of Medicine, $50,42$.

Rebuck, J. W., and Crowley, J. R. (1955). Annals of the New York Academy of Sciences, 59, 757.

Rook, A., Wilkinson, D. S., and Ebling, F. J. G. (editors) (1969). Textbook of Dermatology, $\mathrm{p} .755$. Oxford, Blackweil Scientific.

Rowley, J. D., Blaisdell, R. K., and Jacobsen, L. O. (1966). Blood, 27, 782.

Sandberg, A. A., Ishihara, T., Kikuchi, Y., and Crosswhite, L. H. (1964a). Annals of the New York Academy of Sciences, 113, 663 .

Sandberg, A. A., Ishihara, T., and Crosswhite, L. H. (1964b). Blood, 24, 716.

Sandoz Ltd. (1952). Atlas of Haematology, p. 54. Basle, Sandoz, Ltd.

Shanbrom, E., Collins, Z., and Miller, S. (1960). American fournal of the Medical Sciences, 240,732.

Silverstein, S. (1970). Seminars in Hematology, 7, 185.

Snyder, A. L., Li, F. P., Henderson, E. S., and Todaro, G. J. (1970). Lancet, $1,586$.

Sutnick, A. I., London, T., Blumberg, B. S., and Gerstley, B. J. S. (1971). Fournal of the National Cancer Institute, 47, 923.

Sutton, R. N. P., Bishun, N. P., and Soothill, J. F. (1969). British fournal of Haematology, 17, 113.

Swift, M. (1971). Nature, 230, 370.

Tjio, J. H., and Whang, J. (1962). Stain Technology, 37, 17.

Todaro, G. J., and Martin, G. M. (1967). Proceedings of the Society for Experimental Biology and Medicine, 124, 1232.

Valdimarsson, H. (1972). To be published.

Videbaek, A. (1947). Heredity in Human Leukaemia and its Relation to Cancer. London, Lewis.

Wintrobe, M. M. (1968). Clinical Hematology, p. 236. Philadelphia, Lea and

Febiger.
Zuelzer, W. W., and Cox, D. E. (1969). Seminars in Hematology, 6, 228.

\title{
Acute Zinc Toxicity in Haemodialysis
}

\section{EILEEN D. M. GALLERY, JEANETTE BLOMFIELD, S. R. DIXON}

British Medical fournal, 1972, 4, 331-333

\section{Summary}

A country patient on home haemodialysis suffered acute nausea, vomiting, and fever during dialyses when she

Sydney Dialysis Centre and Medical Research Department, Sydney Hospital, Sydney, N.S.W. 2000

EILEEN D. M. GALLERY, M.B., B.S., Registrar, Immunology and Renal Unit

Children's Medical Research Foundation, Royal Alexandra Hospital for Children, Camperdown, N.S.W. 2050

JEANETTE BLOMFIELD, M.SC., Senior Research Officer

University of Melbourne and Royal Children's Hospital, Parkville, Victoria 3052

S. R. DIXON, M.B., M.R.A.C.P., Research Fellow and Clinical Supervisor Now Renal Physician, Medical Unit, Dunedin Hospital, Dunedin, New Zealand) used water stored in a galvanized tank. She subsequently was found to have severe anaemia with raised plasma and erythrocyte zinc concentrations. Intercurrent hospital haemodialyses and subsequent home dialyses with deionized water were symptom-free.

Experimental haemodialyses of dogs against small concentrations of zinc showed a disproportionate rise in plasma zinc and possible uptake of zinc by the liver.

\section{Introduction}

The possibility that metallic poisoning might occur in dialysed patients as a result of transfer of metals present in low concentrations in dialysis solution has been shown (Maher et al., 1964; Maher et al., 1965) but only copper poisoning has been 
recognized in clinical practice (Matter et al., 1969; Manzler and Schreiner, 1970).

We report the case of a patient on home dialysis who suffered acute toxic symptoms correlating with markedly raised blood zinc concentration when using tank-water for dilution of dialysis fluid. Intercurrent hospital dialyses were uneventful, and subsequent deionization of her home tank-water supply resulted in asymptomatic dialyses.

The binding of zinc by the plasma of experimentally dialysed dogs is also described.

\section{Methods}

Plasma, dialysis fluid, and water levels of zinc and copper and red cell copper were measured by atomic absorption spectrophotometry, as previously described (Blomfield et al., 1969). Red cell zinc was measured by atomic absorption using a 1 in $\mathbf{4 0}$ dilution of packed red cells in deionized water. Normal red cell zinc levels were measured in blood from 10 Red Cross blood donors. Liver zinc concentrations were measured by atomic absorption in ashed wedge biopsy specimens dissolved in $4 \mathrm{~N}$ hydrochloric acid.

Sixteen dogs were experimentally dialysed with the prime purpose of measuring copper uptake, as previously described (Blomfield et al., 1971). Ten dogs were dialysed with Cellophane coils and six with cuprophane coils. Liver biopsy specimens were collected before and after dialysis from four of the dogs dialysed with the Cellophane membranes and all six of the dogs dialysed with the cuprophane membranes.

\section{Case Report}

The patient was a 32-year-old housewife living on a farm in South-west New South Wales. In January 1971 she was admitted to hospital with malignant essential hypertension and renal failure. Her hypertension failed to respond to conservative management, which included peritoneal dialysis and haemodialysis, and she underwent bilateral nephrectomy in March 1971. Postoperatively her blood pressure was within normal limits without antihypertensive therapy.

She was trained for home haemodialysis from 2 March until 15 April using an external arteriovenous shunt, a Drake-Willock artificial kidney without a blood pump, and a Kiil dialyser. During this period she was in excellent health. She was discharged home to continue a regimen of three 10-hour periods of dialysis a week.

Two hours after starting her first dialysis at home she developed severe nausea. vomiting, and fever. These symptoms continued throughout the 10-hour period and were equally severe during each of two subsequent dialyses at home, but subsided between dialyses.

On 22 April she was readmitted to hospital and dialysed there until the 27th, during which time she lost all her symptoms. These, however, recurred during her first and two subsequent dialyses at home. She became progressively weaker and on 4 May was readmitted. Her haemoglobin was found to be $3.5 \mathrm{~g} / 100 \mathrm{ml}$, and a blood film showed moderate polychromasia. She was transfused and dialysed in hospital, again with rapid relief of all symptoms.

At home she used for dialysis rain water which had been collerted from a painted galvanized iron roof, initially into a neighbour's galvanized iron tank where it had been stored for at

Zinc and Copper Concentrations of Tank-zoater and Patient's Blood

\begin{tabular}{|c|c|c|c|}
\hline Date & Sample & $\underset{(\mu \mathrm{g} / 100 \mathrm{ml})}{\text { Zinc }}$ & $\begin{array}{c}\text { Copper } \\
(\mu \mathrm{g} / 100 \mathrm{ml})\end{array}$ \\
\hline $\begin{array}{l}11 / 5 / 71 \\
5 / 5 / 71 \text { ( } 36 \text { hours after } \\
\text { dialysis at home) } \\
18 / 6 / 71 \text { (after } 6 \text { weeks' } \\
\text { dialysis in hospital) }\end{array}$ & $\begin{array}{l}\text { Neighbour's tank-water } \\
\text { Patient's tank-water } \\
\text { Plasma } \\
\text { Red cells } \\
\text { Plasma } \\
\text { Red cells }\end{array}$ & $\begin{array}{r}166 \\
625 \\
700 \\
3,500 \\
158 \\
1,230\end{array}$ & $\begin{array}{c}1 \\
2 \\
43^{*} \\
115 \\
=\end{array}$ \\
\hline
\end{tabular}

- Plasma free copper.

Normal Runges.-Plasma: zinc $60-110 \mathrm{\mu g} / 100 \mathrm{ml}$; copper (free copper) 5-15 $\mu \mathrm{g} / 100$ ml. Red cells: zinc 1,000-1,400 $\mu \mathrm{g} / 100 \mathrm{ml}$, copper $70-105 \mu \mathrm{g} / 100 \mathrm{ml}$. least two-and-a-half months because of drought conditions, and subsequently transferred to her own new galvanized iron tank. Samples of the water and her blood were measured for trace elements.

The results, given in the Table, showed high zinc concentrations in the tank-water, particularly from the new tank. The patient's blood, collected 36 hours after completion of a dialysis at home, showed greatly raised zinc concentrations in plasma and red cells. Blood copper levels were a little above the upper limit of the normal range despite very low water copper concentrations. After six weeks of dialysis in hospital the red cell zinc level had returned to normal but the plasma zinc was still moderately raised.

After investigating various alternatives a deionizer was installed between the patient's water tank and the inflow pipes to her artificial kidney. She was finally discharged home on 3 August and had symptom-free dialyses from that time.

\section{Haemodialysis of Dogs}

The marked capacity of the plasma to bind zinc is illustrated in the Chart. With the Cellophane coils, after 10 minutes of dialysis against fluid with a mean zinc concentration of 78 $\mu \mathrm{g} / 100 \mathrm{ml}$ the mean arterial plasma zinc concentration had

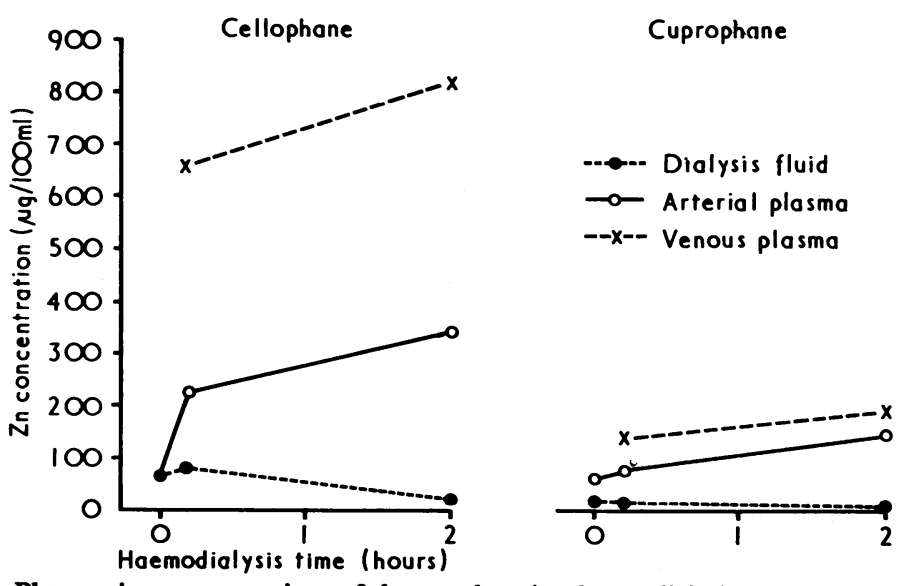

Plasma zinc concentrations of dogs undergoing haemodialysis using Cellophane coil and cuprophane coil.

risen froma predialysis level of $62 \mu \mathrm{g} / 100 \mathrm{ml}$ to $224 \mu \mathrm{g} / 100 \mathrm{ml}$, and the mean difference between arterial blood entering and that leaving the dialysis coil was $432 \mu \mathrm{g} / 100 \mathrm{ml}$. After two hours the arterial level had further increased to $333 \mu \mathrm{g} / 100 \mathrm{ml}$ and the uptake across the coil was still $487 \mu \mathrm{g} / 100 \mathrm{ml}$.

With the cuprophane coils (see Chart) despite a mean dialysis fluid level of only $18 \mu \mathrm{g} / 100 \mathrm{ml}$ the arterial plasma concentration rose from $57 \mu \mathrm{g} / 100 \mathrm{ml}$ to $146 \mu \mathrm{g} / 100 \mathrm{ml}$ after two hours of dialysis, with appreciable uptake of zinc across the membranes.

Increases of liver zinc from a mean predialysis level of $\mathbf{1 3 . 9}$ $\mathrm{mg} / 100 \mathrm{~g}$ of dry liver to $16.5 \mathrm{mg} / 100 \mathrm{~g}$ occurred during the two-hour dialysis in all four of the dogs tested when the Cellophane coils were used. With the cuprophane coils the liver zinc increased in five out of six dogs from a mean predialysis concentration of $16.2 \mathrm{mg} / 100 \mathrm{~g}$ to $19.4 \mathrm{mg} / 100 \mathrm{~g}$ at two hours.

With the Cellophane coils used the zinc was mainly dissolved from zinc oxide adhesive plaster around the coils, whereas with the cuprophane coils the small concentration of zinc in the dialysis fluid was derived from tap-water (Blomfield et al., 1969).

\section{Discussion}

Zinc and copper in dialysis fluid do not equilibrate across the dialysis membrane but are extracted into the blood by the strong affinity of the plasma and red cells for these metals (Blomfield et al., 1969; Blomfield et al., 1971).

Although zinc is regarded as a relatively non-toxic metal, ingestion of large doses is known to cause nausea, vomiting, 
diarrhoea, and fever (Van Reen, 1966). Vomiting and fever occurred on each occasion that the patient was dialysed against fluid diluted with rain water stored in a galvanized iron tank and correlated with a high concentration of zinc in both tank-water and plasma. Additionally she became severely anaemic at a time when she had a grossly raised red cell zinc concentration. The occurrence of toxic symptoms during her first home dialysis implies acute zinc poisoning, and their recurrence with each subsequent dialysis the possibility of acute-on-chronic toxicity.

Gastrointestinal disturbances and haemolysis are symptoms of copper poisoning in haemodialysis (Blomfield et al., 1971), but measurements in this patient disclosed no undue contamination of the dialysis fluid by copper, nor excessive uptake by plasma or red cells. The small increase of plasma free copper may have been due to displacement by zinc of liver copper which had accumulated during previous hospital dialyses and which, in this anephric patient, could not be cleared from the blood by the renal route.

Previous studies of zinc uptake in haemodialysis patients have all shown small rises in arterial plasma zinc concentrations during dialysis, despite dialysis fluid zinc concentrations lower than the plasma levels (Maher et al., 1965; Blomfield et al., 1969; Mansouri et al., 1970; Mahler et al., 1971; Zazgornik et al., 1971), and high predialysis plasma zinc has been found in some patients (Mansouri et al., 1970; Zazgornik et al., 1971), suggesting zinc accumulation.

The experimentally dialysed dogs in this study showed avid plasma binding of zinc to levels many times greater than in the dialysis solution, with a resultant progressive rise in arterial plasma zinc and a possible increase in liver zinc concentrations. Simultaneous copper uptake studies in these dogs have been reported previously (Blomfield et al., 1971). A comparison between zinc and copper uptake from similar bath fluid concentrations shows a relatively greater increase of zinc in plasma returning from the dialysis coil and in arterial plasma but a comparatively lower liver uptake of zinc at the end of the twohour dialysis period.

Although the major excretory route of zinc is in pancreatic juice, zinc accumulates initially in the liver, a fact which has led to the use of the radioisotope ${ }^{\circ} \mathrm{Zn}$ as a liver scanning agent
(Johnston et al., 1967). Intravenous injection of this radioisotope in man has shown a five-minute half-life in the circulation and a prompt removal and concentration by the liver (Johnston et al., 1967).

These studies emphasize the dangers of metal poisoning in haemodialysis. The large volumes of water used for haemodialysis and the binding of metals by plasma proteins can lead to acute or cumulative toxicity from water with metal concentrations which are within acceptable limits for drinking purposes.

The haemodialysis coils used in the experimental dialysis of dogs were supplied by Travenol Laboratories Pty., Rosebery, N.S.W. We would like to thank Dr. J. H. Stewart, Dr. D. C. Cattran, and Dr. J. A. Charlesworth, of Sydney Hospital, Sydney, Miss K. L. Warton, of Royal Alexandra Hospital for Children, Sydney, and Dr. D. A. McCredie, of the Royal Children's Hospital, Melbourne, for their contributions to these studies.

Requests for reprints should be addressed to E.D.M.G., Medical Research Department, Sydney Hospital, Sydney, N.S.W. 2000, Australia.

\section{References}

Blomfield, J., McPherson, J., and George, C. R. P. (1969). British Medical Fournal, 2, 141.

Blomfield, J., Dixon, S. R., and McCredie, D. A. (1971). Archives of Internal Medicine, 128, 555 .

Johnston, G. S., Hupf, H. B., Gotshall, E., and Kyle, R. W. (1967). American fournal of Roentgenology, Radium Therapy and Nuclear Medicine, 101, 548.

Maher, J. F., Freeman, R. B., Setter, J. G., Rubin, M., and Schreiner, G. E. (1964). Transactions of the American Society for Artificial Internal Organs, 10, 332.

Maher, J. F., Freeman, R. B., Schmitt, G., and Schreiner, G. E. (1965) Transactions of the American Society for Artificial Internal Organs, 11, 104.

Mahler, D. J., Walsh, J. R., and Haynie, G. D. (1971). American fournal of Clinical Pathology, 56, 17.

Mansouri, K., Halsted, J. A., and Gombos, E. A. (1970). Archives of Internal Medicine, 125, 88.

Manzler, A. D., and Schreiner, A. W. (1970). Annals of Internal Medicine, 73, 409.

Matter, B. J., Pederson, J., Psimenos, G., and Linderman, R. D. (1969). Transactions of the American Society for Artificial Internal Organs, 15, 309.

Van Reen, R. (1966). Zinc Metabolism, ed. A. S. Prasad, p. 411. Springfield, Illinois, Thomas.

Zazgornik, J., Kotzaurek, R., and Schmidt, P. (1971). Klinische Wochenschrift, 49, 278.

\section{Plasma Steroid and Luteinizing Hormone Levels during Prostaglandin F2 $\alpha$ Administration in Luteal Phase of Menstrual Cycle}

\section{KEITH HILLIER, ANGELA DUTTON, C. S. CORKER, ALBERT SINGER， M. P. EMBREY}

British Medical fournal, 1972, 4, 333-336

\section{Summary}

An intravenous infusion of prostaglandin $F_{2} \alpha$ (12.5$250 \mathrm{\mu g} / \mathrm{min}$ ) was administered in four volunteers in the mid-late luteal phase and three in the early luteal phase of the menstrual cycle.

Frequent measurement of plasma progesterone, oestrogens, and luteinizing hormone( LH) showed that adminis-

Nuffield Department of Obstetrics and Gynaecology, University of Oxford, The John Radclife Hospital, Headington, Oxford

KEITH HILLIER, B.SC., PH.D., Research Fellow

ALBERT SINGER, M.B., M.R.C.O.G., Senior Registrar

M. P. EMBREY, M.D., F.R.C.O.G., First Assistant

M.R.C. Neuroendocrinology Unit, Department of Human Anatomy, South Parks Road, Oxford

ANGELA DUTTON, M.I.BIOL., Research Assistant

C. S. CORKER, B.SC., D.PHIL., Research Worker tration of high doses depressed plasma progesterone levels in the late luteal phase and caused concomitant side effects. Levels of progesterone in the early luteal phase were unafiected. In both phases oestrogen and LH levels were little altered. In two subjects, hourly progesterone levels measured throughout the day at a similar time in a subsequent control menstrual cycle showed an appreciable variation in one but steady levels in the second. This variation may contribute to the magnitude of the fall in progesterone noted during the infusion of prostaglandins.

\section{Introduction}

Experimental evidence indicating that the prostaglandins possess luteolytic activity has suggested the possibility of a novel approach to fertility control. Prostaglandin $\mathrm{F}_{2} \alpha\left(\mathrm{PGF}_{2} \alpha\right)$ acts as a luteolysin in many non-primate laboratory animals (Blatchley 